\title{
DESIGN OF MOBILE EXPERT SYSTEM FOR DIABETES RISK DIAGNOSIS AND INFORMATION
}

\author{
Anindito Yoga Pratama ${ }^{1}$, Dewi Agushinta R. ${ }^{2}$, and Remi Senjaya ${ }^{1}$ \\ ${ }^{1}$ Department of Informatics Engineering, Faculty of Technology Industry, Gunadarma University \\ ${ }^{2}$ Department of Information System, Faculty of Computer Science \& Information Technology, \\ Gunadarma University \\ E-mail: aga.ti_92@student.gunadarma.ac.id
}

\begin{abstract}
Along with the development of information technology, mobile applications are widely applied to various fields. The use of mobile applications is considered effective to help user in understanding the problem. One example of the application of mobile applications needed today is an application that can help to determine a wide range of health. The designs discussed in this paper are the structure of the navigation and layout design of mobile applications created. There is a navigation structure and eight layout designs such as splash screen page, main menu page, diabetes risk test page, result page, diabetes prevention info page, food information page, list of hospitals page, and help page. The purpose of this paper is to design of mobile application for diabetes risk diagnosis and information based on android.
\end{abstract}

Keywords: Android, Design, Exepert System, Mobile Application, Diabetes Risk

\begin{abstract}
Abstrak
Seiring dengan perkembangan teknologi informasi, aplikasi mobile secara luas diterapkan pada berbagai bidang. Penggunaan aplikasi mobile dianggap efektif untuk membantu pengguna dalam memahami masalah. Salah satu contoh penerapan aplikasi mobile yang dibutuhkan saat ini adalah sebuah aplikasi yang dapat membantu untuk menentukan berbagai kesehatan. Desain dibahas dalam makalah ini adalah struktur navigasi dan tata letak desain aplikasi mobile yang diciptakan. Ada struktur navigasi dan delapan desain tata letak seperti halaman splash screen, halaman menu utama, halaman pengujian resiko diabetes, halaman hasil, diabetes pencegahan halaman info, halaman informasi makanan, daftar halaman rumah sakit, dan halaman bantuan. Tujuan dari makalah ini adalah untuk merancang aplikasi mobile diagnosis dan informasi resiko diabetes berbasis android.
\end{abstract}

Kata kunci: Android, Aplikasi Mobile, Desain, Resiko Diabetes, Sistem Pakar

\section{Introduction}

Technological developments should facilitate access to information on human affairs. Ease it aims to help people resolve problems and issues they are facing. One of the problems that can be solved with technology is a diagnosis of the disease. One of them is a disease of diabetes mellitus (DM) that can infect humans. In Indonesia, according to the 1993 survey, the prevalence of diabetes in the cities of 6-20 years is $0.26 \%$, age over 20 years is $1.43 \%$, and age above 40 years is $4.16 \%$, while the countryside age over 70 is $1,47 \%$ [1].

One example of the Information technology (IT) is a smartphone. Operating system on a mobile device that is a trend today is Android OS. Popularity phones carrying the Android OS was increasingly rampant. The number of mobile phone users with the green robot operating system is increasingly rising to leave a lot of its competitors. Varian cell phone is numerous and is dominated by the lower middle class. They chose android smartphone. An increasing number of Android users in 2012 were also very rapidly by $25 \%$ from a year ago.

The authors designed mobile application for diabetes risk diagnosis and information based on android [2].

In helping users to determine the level of diabetes risk and information about diabetes risk, so it will be easier to design in the manufacture of mobile applications. Users are expected use mobile application easier and more convenient.

The formulation of the problem to be addressed in this paper is how to design a mobile application interface so interesting and appropriate to the needs of the user. 


\section{Literature Review}

\subsection{Expert System}

Expert Systems (ES) is a software package of decision making or problem solving to achieve an equivalent level of performance - or even more - with a human expert in some specialized field and usually narrow problem area. The basic idea behind ES, applied artificial intelligence technology, is simple. Expertise transferred to a computer expert. This knowledge is then stored in the computer, and the user running the computer for specific advice is necessary. ES asks the facts and made inferences and come to a particular conclusion. Then, like a human consultant, he advises and explains no expert. If necessary, the logic behind the advice will be given. Currently ES is used in thousands of organizations and systems to support multiple tasks [3].

Expert systems are composed by two main parts, namely the development environment and consultation environment [4].

\subsection{Knowledge Base}

In the development of knowledge-based systems, the extracted knowledge incorporated into the computer program by a process called knowledge representation. Knowledge representation system is a combination of two elements of data structures and procedures to interpret (interpretive procedure) for the use of knowledge included in data structure.

Rules of production system are one of the most popular knowledge representations in an expert system. The system is represented in the form:

\section{IF [condition] THEN [action]}

This rule was later incorporated into knowledge base. At the time incorporated into the inference engine, set the rules apply in synergy, providing better results than the sum of the results of individual rules [3].

\subsection{Navigation Structure}

Navigation structure is one important element in a plan. Navigation structure is the design of employment relationships or chain which describes the overall system. Navigation structure facilitates the linkage analyze all objects that exist within the system. The basic form of navigation structures commonly used in the manufacturing process are four kinds of multimedia applications, namely linear navigation structure, hierarchy, nonlinear and composite [5].

Composite navigation structure is a combination of linear navigation structure, hierarchy, and non-linear. Navigation structure is called a mixture of free navigation structure, the point is if a display requires branching [6].

\subsection{Android}

Android is an operating system for mobile devices such as smartphones and tablet computers. It is developed by the Open Handset Alliance led by Google. Android consists of a kernel based on the Linux kernel, with middleware, libraries and APIs written in C and application software. It is running on an application framework which includes Javacompatible libraries based on Apache Harmony. Android uses the Dalvik virtual machine with just-in-time compilation to run Dalvik dex-code (Dalvik Executable), usually translated from Java byte code [7].

\section{Research Method}

The research method used in this paper is a study method combined field studies methods literature and direct method in which the materials needed to conduct this study in part derived from books or the internet and most directly obtained from the field studies. Such methods have the following steps:

1. Literature studies to search about designing a mobile application of this research.

2. Designing mobile application interface tailored to the user needs.

\section{Result and Discussion}

This section will discuss in detail starts from designing expert system, designing knowledge base, navigation structure, and layout design.

\subsection{Designing Expert System}

Expert system to determine a person's diabetes risk is actually just a tool for early prevention for diabetes. The advantages of an expert system lie in its ability to work continuously and are in a condition that maximum. The expert system was created not to replace the position of an expert, but as a tool in decision-making certainty, since there may be many alternatives chosen appropriately.

The design of an expert system to determine the risk of diabetes requires two stages. The first stage is to transform a variety of information about diabetes risk by an expert (in this case the doctor) into an expert system. It has also added information from several books and studies that address diabetes risk, besides collecting information from an expert. 
The second stage is applying the information gained into the components of expert systems, after having obtained the necessary information.

\subsection{Designing Knowledge Base}

The knowledge base is the core program of an expert system which is a knowledge representation. Knowledge base obtained after the information is organized in a structured way.

In this issue, it determined what elements are involved in the risk of diabetes such as diabetes risk factors and the level of diabetes risk. Experts used in this application are a doctor and literature references obtained from the study by the Sacramento Native American Health Center Inc. (SNAHC) [7].

In the design of the knowledge base is to define a rule base representation of the knowledge base. Determining the level of diabetes risk used a series of statements, a series of statements which should be selected or answered with yes or no.

From the answers it was then diagnosed traced by counting the number of points for each question given. The question and the score of each question can be seen in table I.

TABLE I

QUESTIONS FOR DIABETES RISK TEST

\begin{tabular}{lcc}
\multicolumn{3}{c}{ QUESTIONS FOR DIABETES RISK TEST } \\
\hline \multicolumn{1}{c}{ At-Risk Questions } & Yes \\
\hline $\begin{array}{l}\text { Are you a woman who has had a baby } \\
\text { weighing more than 4.5 kg at birth? }\end{array}$ & 1 & 0 \\
$\begin{array}{l}\text { Do you have a sister or brother with } \\
\text { diabetes? }\end{array}$ & 1 & 0 \\
$\begin{array}{l}\text { Do you have a parent with diabetes? } \\
\text { Are your weight between 65 and 111 }\end{array}$ & 1 & 0 \\
kg and your height between 130 and & 5 & 0 \\
$184 \mathrm{~cm}$ ? & & \\
$\begin{array}{l}\text { Are you under 65 years old and get } \\
\text { little or no exercise in a typical day? }\end{array}$ & 5 & 0 \\
$\begin{array}{l}\text { Are you between 45 and 64 years old? } \\
\text { Are you 65 years old or older? }\end{array}$ & 5 & 0 \\
\hline
\end{tabular}

After looking at table I we can calculate the risk score, get results of calculations carried out, and classify levels of diabetes risk. The level of diabetes risk based on scores obtained can be seen in table I.

TABLE II

LEVEL OF DIABETES RISK

\begin{tabular}{ll}
\hline Scoring & Level of Diabetes Risk \\
\hline 0 to 2 points & very low risk \\
3 to 9 points & low to medium risk \\
10 or more points & high risk \\
\hline
\end{tabular}

These obtained information from table I and II will be used to implement into android.

\subsection{Navigation Structure}

Navigation structure in this application is composite. Composite Navigation structure is a combination of linear structure, hierarchy, and nonlinear. Users can browse freely, but it is limited by linear presentation of a display or important information, as well as arranged data in a hierarchical.

This phase will explain the applications design of the navigation structure run on mobile devices users. From this structure we can see pages relation exist on the application. Figure 1 is the design of navigation structure of the applications developed.

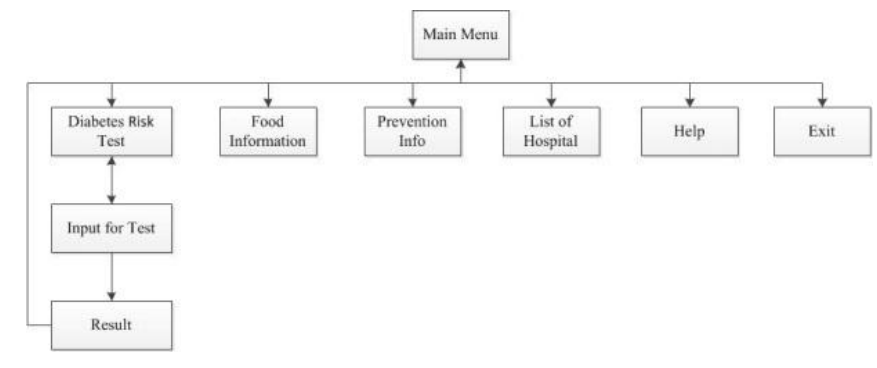

Fig 1. Navigation Structure

The navigation structure is clearly. Lines with two arrows indicate the user can move to next page and can return to previous page. A line with an arrow indicates that users can simply go to next page but cannot return to previous page.

\subsection{Layout Design}

Layout design consists of several pages made to facilitate user in mobile application. At this subsection the layout used in this mobile application will be designed, including layout design for splash screen page, main menu page, diabetes risk test page, result page, diabetes prevention info page, food information page, list of hospital page, and help page.

1. Splash Screen Page : The first page appears when application run. This page appears only once at the beginning and came up just two seconds and then switch to main menu page. Splash screen page has a background and there is logo applications in middle of the page, see figure 2 for more details.

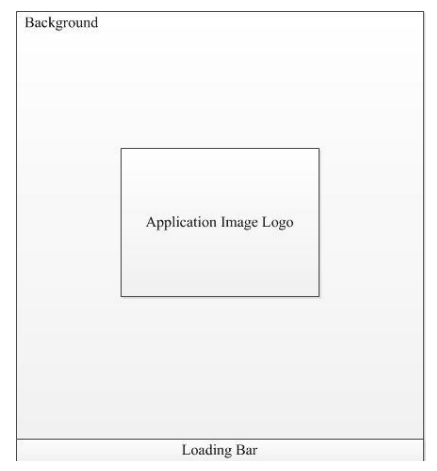

Fig 2. Splash Screen Page 
2. Main Menu Page: The initial view when the program starts. There are six image buttons showed in figure 3 . User can select six options by clicking the button, such as IMAGEBUTTON1 as Diabetes Risk Test, IMAGEBUTTON2 as Hospital, IMAGEBUTTON3 as Diabetes Prevention Info, IMAGEBUTTON4 as Exit, IMAGEBUTTON5 as Food Information, and the last IMAGEBUTTON6 as Help.

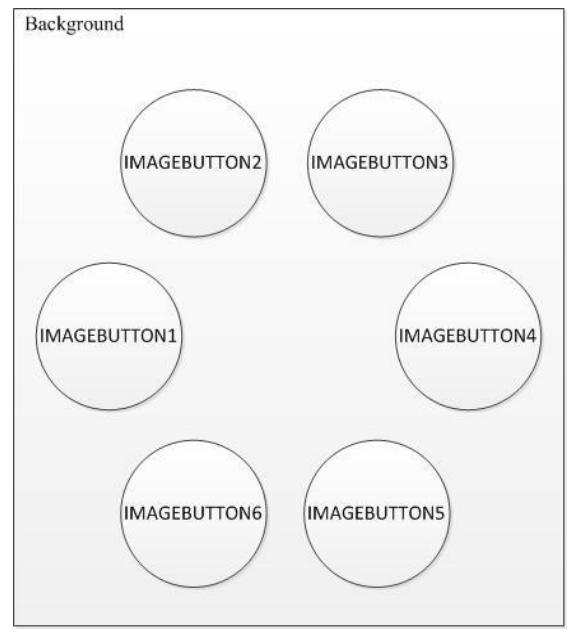

Fig 3. Main Menu Page

3. Diabetes Risk Test Page : An input page and the questions given on this page. TEXTVIEW1 is used for questions while the RADIOBUTTON1 and RADIOBUTTON2 are used for the answers. This page contains two buttons, IMAGEBUTTON1 as Next and IMAGEBUTTON2 as Back, see figure 4 for more details.

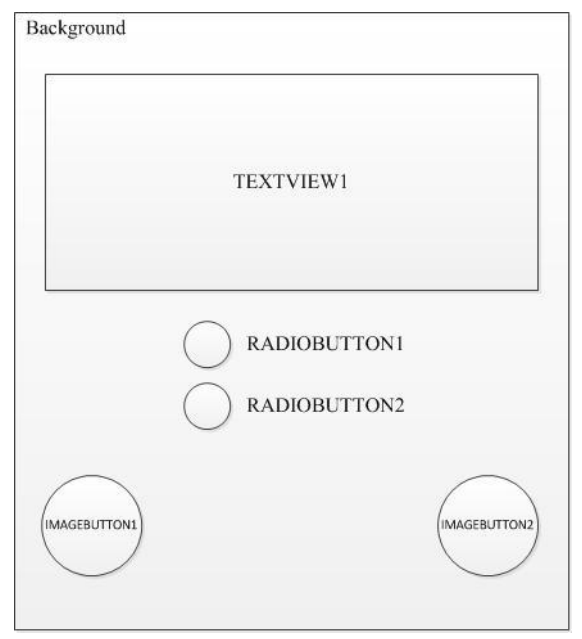

Fig 4. Diabetes Risk Test Page
4. Result Page : A page presents the results of input made by user on diabetes risk test page. In this page, the result will be displayed in the TEXTVIEW1, and IMAGEBUTTON1, see figure 5 for more details.

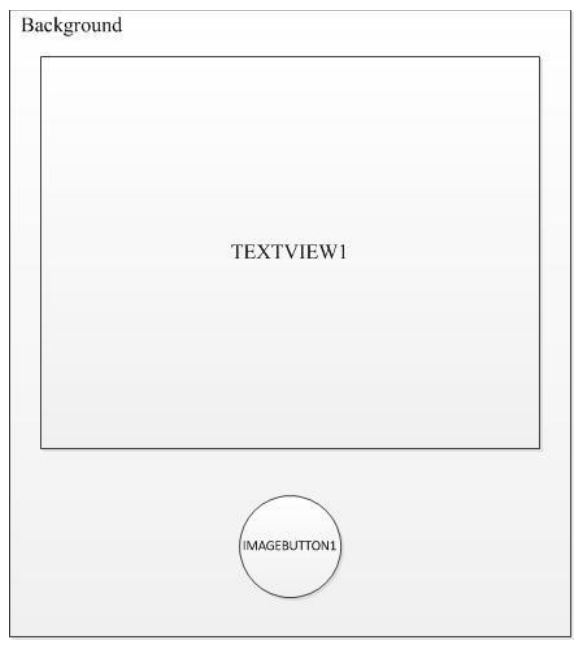

Fig 5. Result Page

5. Food Information Page : A page to find food information for diabetic candidate. This page consists of two tab menus; they are men with IMG1 as the icon and women with IMG2 as the icon. On each tab contains TEXTVIEW1, see figure 6 for more details.

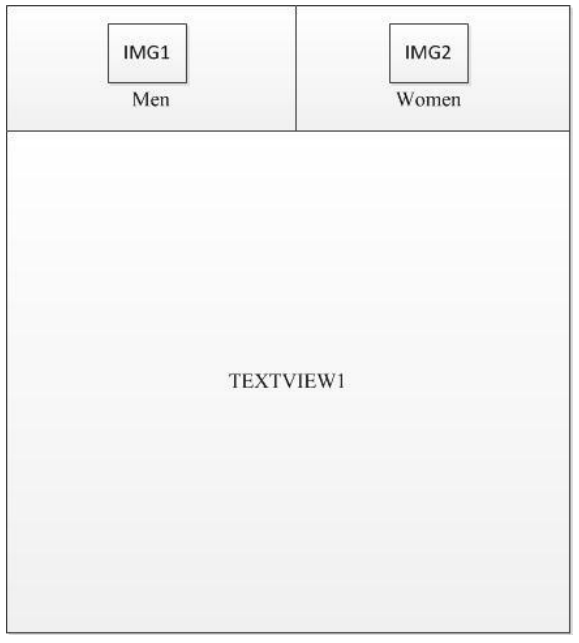

Fig 6. Food Information Page

6. Diabetes Prevention Info Page : A page to find the information for the prevention of diabetes risk. In this page, the information will be displayed in TEXTVIEW1 with SCROLLVIEW1, see figure 7 for more details. 


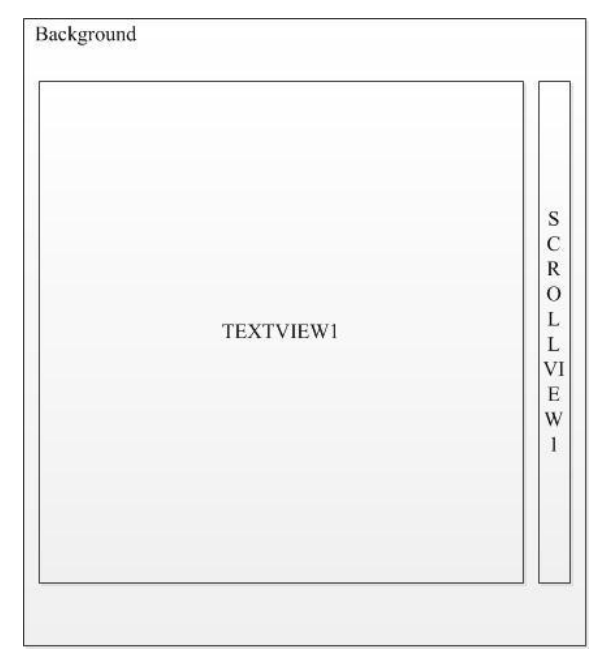

Fig 7. Diabetes Prevention Info Page

7. List of Hospital : A page will display name and phone number of hospital provides diabetes program, see figure 8 for more details.

\begin{tabular}{|c|c|c|}
\hline Name & & Telephone \\
\hline \multicolumn{3}{|c|}{ LISTVIEW1 } \\
\hline \multicolumn{3}{|c|}{ LISTVIEW2 } \\
\hline \multicolumn{3}{|c|}{ LISTVIEW3 } \\
\hline \multicolumn{3}{|c|}{ LISTVIEW4 } \\
\hline \multicolumn{3}{|c|}{$\begin{array}{l}\circ \\
:\end{array}$} \\
\hline \multicolumn{3}{|c|}{ LISTVIEWn } \\
\hline
\end{tabular}

Fig 8. List of Hospital Page

8. Help Page : A page to find information for helping user run the application. In this page, the information will be displayed in TEXTVIEW1 with SCROLLVIEW1, see figure 9 for more details.

\section{Conclusion}

Design that has been described above can be useful for subsequent conduct of mobile application expert system for diagnosing diabetes risk with information development.
With the creation of this design is expected that application developers can create mobile applications is to allow users to meet the information needs of health problems, especially diabetes risk and easy to operate.

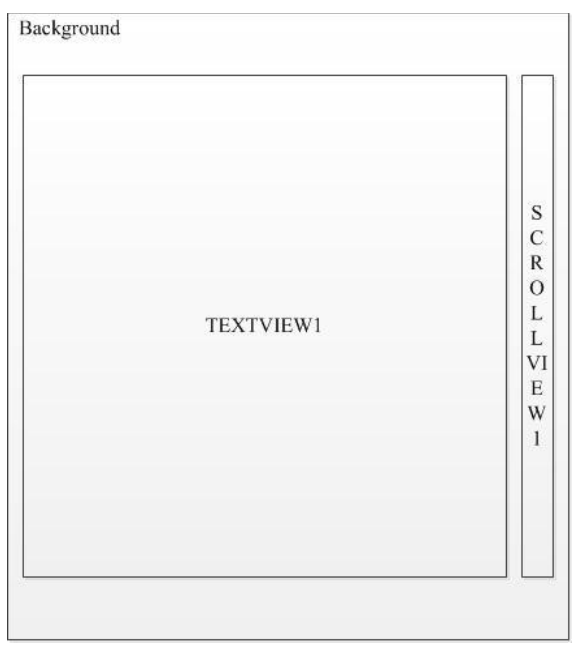

Fig 9. Help Page

\section{References}

[1] H. Hamid, "Diet therapy diabetes melitus." UMM Press. Malang, 2009.

[2] R. Senjaya, Anindito YP, and Dewi Agushinta R., "Mobile Application for Diabetes Risk Diagnosis and Information Based On Android", World of Computer Science and Information Technology Journal (WCSIT), 3(2), 2013, 44-49.

[3] J. E. A. Efraim Turban and T.-P. Liang., "Decision Support System". Yogyakarta: Andi Offset, 2005.

[4] A. Mahendra, "Struktur navigasi," 2009, Literature Study.

[5] W. Nugroho, "Storyboard," 2012, Literature Study.

[6] E. Turban, "Decision support and expert systems: management support systems", ser. Macmillan series in information systems. Macmillan, 1993.

[7] W. M. Lee, "Beginning Android Application Development (Wrox Programmer to Programmer)". Wiley Publishing, 2011.

[8] S. N. A. H. C. Inc., "At-risk paper diabetes test," 2009. 